\title{
Suitability of Carbon and Nitrogen Management Indices for the Evaluation of Soil Organic Matter under Different Soil Management Practices in a Productive Vineyard
}

\author{
Vladimír Šimanský1*, Jarmila Horváthová2, Jerzy Jonczak³ ${ }^{3}$ Nora Polláková' \\ 1 Department of Soil Science, Faculty of Agrobiology and Food Resources, Slovak University of Agriculture, \\ Tr. A. Hlinku 2, 94976 Nitra, Slovakia \\ 2 Department of Languages, Faculty of Economics and Management, Slovak University of Agriculture, \\ Tr. A. Hlinku 2, 94976 Nitra, Slovakia \\ ${ }^{3}$ Institute of Agriculture, Department of Soil Science, Faculty of Agriculture and Biology, Warsaw University \\ of Life Sciences - SGGW, Nowoursynowska Str. 159, building no. 37, 02-776 Warszawa, Poland \\ * Corresponding author's e-mail: vladimir.simansky@uniag.sk
}

\begin{abstract}
Soil organic matter (SOM) is considered to be the most important part in the soil. $\mathrm{C}$ and $\mathrm{N}$ and their forms are most often used to evaluate SOM. In the last decades, $\mathrm{C}$ indices have begun to be used to assess soil quality for $\mathrm{C}$ changes in SOM due to the different soil management. Since C cycle is closely related to N, there is an assumption that $\mathrm{N}$ indices (derived in the same way as $\mathrm{C}$ indices) will be sensitive to $\mathrm{N}$ changes in SOM under the different soil management. The objective of the study was to evaluate the extent of $\mathrm{C}$ and $\mathrm{N}$ indices on $\mathrm{C}$ and $\mathrm{N}$ changes in $\mathrm{SOM}$ (in Rendzic Leptosol) under the different soil management practices (1. G: grass and no fertilization - as control; 2. T: tillage; 3. T+FYM: tillage + farmyard manure; 4. G+NPK3: grass + NPK 125-50-185 kg ha' ${ }^{-1}$ 5. G+NPK1: grass + NPK 100-30-120 $\mathrm{kg} \mathrm{ha}^{-1}$ ) in a productive vineyard (Nitra-Dražovce; Slovakia) during the period of 13 years. The results showed that the soil organic carbon (SOC) was reduced by $26 \%$ compared to G because of intensive cultivation on one hand, but on the other hand, in T + FYM treatment no significant changes in SOC over the 13 years of the experiment were observed. A higher labile carbon $\left(\mathrm{C}_{\mathrm{L}}\right)$ content was in $\mathrm{G}+\mathrm{NPK} 3$ then follows: $\mathrm{G}+\mathrm{NPK} 1>\mathrm{G}>\mathrm{T}+\mathrm{FYM}>\mathrm{T}$ for topsoil $(0-30 \mathrm{~cm})$. In topsoil, carbon lability increased after a higher level of mineral fertilization, while in subsoil $(30-60 \mathrm{~cm})$ after intensive cultivation. The values of CPI for topsoil decreased in the following order: $\mathrm{G}+\mathrm{NPK} 1>\mathrm{T}+\mathrm{FYM}>\mathrm{G}+\mathrm{NPK} 3>\mathrm{T}$. Based on CMI values, intensive $\mathrm{C}$ changes in the $\mathrm{SOM}$ due to the soil management practices were observed in $\mathrm{T}$ treatment. The highest accumulation of carbon and decomposable organic matter occurred in G+NPK3. Incorporation of FYM, and both rates of NPK increased values of NMI by 45, 47 and 36\% respectively compared to intensive tilled treatment for topsoil. The highest values of the NPI were detected because of farmyard manure application and mineral fertilization at a higher rate (NPK3) for topsoil and because of intensive cultivation between vine rows as well as plowing of FYM for subsoil.
\end{abstract}

Keywords: vineyard, soil organic matter, carbon indexes, nitrogen indexes

\section{INTRODUCTION}

Soils play multiple roles in the quality of life throughout the world, not only as the resource for food production, but also as the support for our structures, the environment, the medium for waste disposal, water, and the storage of nutrients. Healthy soil can sustain biological productivity, maintain environmental quality, and promote plant and animal health. Understanding the impact of land management practices on soil properties and processes can provide useful indicators of economic and environmental sustainability [Hernández-Soriano 2013]. As pointed by [Komasuzaki and Ohta 2007], the human population burden, together with the rapid industrial expansion, has seriously impacted the functioning of the soil resource. 
Vineyards are based in less suitable places compared to other crops. These are often locations on slopes with lower quality and stony soils [Šimanský et al. 2016]. However, the right winegrower makes sure that the vineyards have the longest possible lifespan, which is limited by the choice of location for the future vineyard. Establishing a vineyard is not an easy task and often it is a matter of several years. The soil is intensively fertilized before the vineyard is established using manure and mineral fertilizers, which are applied deeper into the soil profile in comparison to standard crops, and the soil $\mathrm{pH}$ is adjusted. As a result of these steps, the original natural soils are significantly transformed into Anthrosols.

Even though the vineyards are established in less suitable places, the vine has high demands for optimal growth and development. White [2015] stated that the vine needs soil with optimal physical, chemical, and biological properties. The different soil management practices, that are applied after the establishment in the vineyard, determine its sustainable cultivation. For example, since 1970 in France, the method of growing vines has undergone several significant changes. Intensive tillage of vineyards was limited, terracing and chemical protection against weeds were introduced. In the frame of the soil protection, many experimental results from the different wine-growing regions recommend several ways of growing vines, such as: regulated chemical control of weeds between vine rows, mulching, permanent grassing [Šimanský et al. 2016]. Celette et al. [2008] recommend growing intercrops in deep-soil vineyards. Since, as mentioned above, the vine needs nutrients, its optimal cultivation requires control and regulation of the nutrient regime, which has not only economic but also ecological consequences [Ložek et al., 2017]. In Slovakia, within the Agrochemical Soil Testing, the $\mathrm{pH}$ and content of macronutrients are tested in 5-year cycles, but less attention is paid to other soil indicators. In general, soil quality can be expressed through indicators - measurable properties of soil or plants that provide rigorous information about the competence of soil functions [Hernández-Soriano 2013]. Soil organic matter (SOM) is one of the most important features of soil [Rutkowska and Pikula 2013, Garousi et al. 2021)] and one of the crucial indicators of soil fertility [Bendi et al., 2015]. Currently, in the era of rapidly changing civilization, leading to changes in climate and soil conditions, SOM content becomes increasingly important, not only for the proper functioning of ecosystems but also for the socio-economic development of many regions of the world [Komasuzaki and Ohta 2007]. During the last years in the EU countries, the progressive degradation of SOM was observed. The same trend is observed in Slovakia [Kobza et al. 2017]. Thus, this issue was reflected in the EU New Soil Strategy [2021] on which the actual reduction of SOM content was listed as one of the most important problems and the associated efforts to increase SOM as well as restore carbonrich ecosystems. It is possible to find the solution by application of suitable soil management practices in the context of increasing SOM, especially in productive vineyards, and not only in Slovakia. The progressive decline in SOM is associated with soil fertility [Pereg et al. 2018] and traditional intensive agricultural practices negatively impact soil quality, leading to increased erosion in the many vineyard regions [Obia et al. 2016]. Therefore, knowledge and quantification of the contribution of sustainable vineyard management impact are needed [Novara et al. 2020].

Soil organic matter (SOM) is a heterogeneous and dynamic substance that varies in $\mathrm{C}$ and $\mathrm{N}$ content [Tong et al. 2014]. Soil organic carbon (SOC) and total nitrogen in the soil $\left(\mathrm{N}_{\mathrm{t}}\right)$ are closely associated with a wide range of physical, chemical, and biological properties of soil and thus they play an important role in soil processes and functioning and they are used as significant indicators of soil quality [de Moraes Sá et al. 2018]. SOC is the basis of soil fertility. It releases nutrients for plant growth, promotes the structural, biological, and physical health of the soil, and is a buffer against harmful substrates [Wang et al. 2021]. Nitrogen is generally the most common growth-limiting nutrient in ecosystems [Garousi et al. 2021]. In the scientific studies, $\mathrm{SOM}$ is quantified through $\mathrm{C}$ and $\mathrm{N}$ forms with an emphasis on labile forms because they respond more sensitively to the changes in SOM [Szombathová 1999, Bendi et al. 2015], mainly due to the response to agricultural management changes [Bendi et al. 2015]. Rather $\mathrm{C}$ and its forms than $\mathrm{N}$ are often determined/evaluated with relation to SOM. Even Blair et al. [1995] proposed to assess changes in SOM using the calculated $\mathrm{C}$ indices as: carbon lability, carbon lability index, carbon pool index, and carbon management index.

However, in SOM, the changes through different soil management practices occur not only 
in $\mathrm{C}$ but also in the content of labile N. Therefore, there was the intention to apply $\mathrm{C}$ indices according to Blair et al. [1995] to the $\mathrm{N}$ content and to find out whether they react as sensitively to the changes in soil management practices as in the case of C indices [Contheh et al. 1999, Szombathová 1999, Viera et al. 2007, Šimanský and Polláková, 2016]. Šimanský et al. [2018] based on $\mathrm{C}$ indices - on the same principle they created/calculated $\mathrm{N}$ indices and subsequently verified them in a laboratory experiment. Howev$\mathrm{er}$, in this study, only $\mathrm{N}$ indices were subsequently assessed as the indicators of changes in SOM. So far, we have not had information that these $\mathrm{N}$ indices in relation to $\mathrm{N}$ changes in SOM would be applied to evaluate due to the different soil management practices in field experiments and were compared with $\mathrm{C}$ indices.

Therefore, in this study, the extent of the effect of soil management in a productive vineyard (1.) on changes in SOM through $\mathrm{C}$ and $\mathrm{N}$ - their forms, as well as their calculated indices, was quantified, (2.) studied dynamics of changes in SOM, and (3.) assessed relations between $\mathrm{C}$ and $\mathrm{N}$ indexes.

\section{MATERIAL AND METHODS}

\section{Characteristics of study locality}

This study was based on the long-term experiment established at the locality of Nitra-Dražovce $\left(48^{\circ} 21^{\prime} 6.16^{\prime \prime} \mathrm{N} ; 18^{\circ} 3^{\prime} 37.33^{\prime \prime} \mathrm{E}\right)$ in the year 2006 . The experimental area (vineyard) is located in the Nitra winegrowing area (Slovakia) on the southwest side of the Tribeč Mountain. In the $11^{\text {th }}$ century, the southern slopes of the Zobor hills were deforested and vineyards were planted. Today, the locality is used as a horticulture area and for growing plants to produce wines. Before the vineyard establishment, the locality was abandoned, which resulted in prevailing grass growth. In the year 2000, the vines (Vitis vinifera L. cv. Chardonnay) were planted in rows of $3 \times 1 \mathrm{~m}$ - the total of 3,300 plants per hectare and were trained using the Rheinish-Hessian system. The local climate is temperate, with a mean annual temperature of $\geq 10^{\circ} \mathrm{C}$ and rainfall of $550 \mathrm{~mm}$. The geologic substrate of the studied area is mainly composed of a series of Mesozoic sedimentary rocks with a predominance of Cretaceous, Jurassic, and Triassic limestones. The soil is classified as sandy
Rendzic Leptosol with strong anthropogenic influence [WRB, 2015]. The particle-size distribution is $569 \mathrm{~g}$ sand $\mathrm{kg}^{-1}, 330 \mathrm{~g}$ silt $\mathrm{kg}^{-1}$, and $101 \mathrm{~g}$ clay $\mathrm{kg}^{-1}$. Rock fragments represent $8 \%$ of soil bulk (in topsoil, 0-30 cm). Before the experiment establishment in 2006 the soil samples (depth 0 $-30 \mathrm{~cm}$ ) contained on average $17.0 \pm 1.6 \mathrm{~g} \mathrm{~kg}^{-1}$ organic carbon, $1,067 \pm 103 \mathrm{mg} \mathrm{kg}^{-1}$ total $\mathrm{N}, 99$ $\pm 8 \mathrm{mg} \mathrm{kg}^{-1}$ available P, $262 \pm 15 \mathrm{mg} \mathrm{kg}^{-1}$ available $\mathrm{K}$, the Bs percentage was $99.3 \pm 0.01 \%$, and $\mathrm{pH}_{\mathrm{H} 2 \mathrm{O}}$ value $7.18 \pm 0.08$.

\section{Experimental design}

The experiment comprises 5 soil management practices in the productive vineyard (vineyard planted in 2000, the experiment established in 2006). The experiment was conducted on a randomized complete block design with four repetitions. It included the following treatments: 1. Control $(G)$ treatment. The grass was sown in and between the vine rows, without fertilization. 2. Tillage (T). Every year medium tilth to the depth of $0.25 \mathrm{~m}$ with intensive cultivation between vine rows during the growing season (using hoes) - three times on average, without fertilization. 3. Tillage + Farmyard Manure $(T+F Y M)$. Medium tilth to the depth $0.25 \mathrm{~m}$ with plowed farmyard manure (FYM) in a dose of $40 \mathrm{tha}^{-1}$ and intensive cultivation between vine rows during the growing season. 4 . G+NPK1 - every year the application of lower doses of NPK fertilizer, and 5. G+NPK3 - every year the application of high doses of NPK fertilizer. In G, G+NPK1, and $\mathrm{G}+\mathrm{NPK} 3$ treatments, the grass (Lolium perenne $50 \%+$ Poa pratensis $20 \%+$ Festuca rubra commutata $25 \%+$ Trifolium repens $5 \%$ ) was sown in and between vine rows in 2003. In T + FYM treatment, used doses of farmyard manure at the plots were $40 \mathrm{tha}^{-1}$ every 4 years beginning from 2005. As the farmyard manure - poultry manure was used which contains in dry matter $55 \%$ of organic substances, total $\mathrm{N} 2.8 \%, \mathrm{P}_{2} \mathrm{O}_{5} 1.3 \%, \mathrm{~K}_{2} \mathrm{O}$ $1.2 \%$, and $\mathrm{pH} 6-8$. Doses of NPK fertilizers in $1^{\text {st }}$ intensity for vineyards (NPK1) corresponding to: $80 \mathrm{~kg} \mathrm{~N} \mathrm{ha}^{-1}, 35 \mathrm{~kg} \mathrm{P} \mathrm{ha}^{-1}$ and $135 \mathrm{~kg} \mathrm{~K} \mathrm{ha}^{-1}$ [Fecenko and Ložek 2000]. The used fertilizer was Duslofert Extra 14- 10-20-7 and real doses of nutrients applied in the treatment were: $100 \mathrm{~kg}$ $\mathrm{N} \mathrm{ha}^{-1}, 30 \mathrm{~kg} \mathrm{P} \mathrm{ha}{ }^{-1}, 120 \mathrm{~kg} \mathrm{~K} \mathrm{ha}^{-1}$. The dose of nutrients was divided: $1 / 2$ applied into the soil in the spring (bud burst - in March) and 1/2 in flowering (in May). The doses of NPK fertilizers in $3^{\text {rd }}$ 
intensity for vineyards (NPK3) corresponding to: $120 \mathrm{~kg} \mathrm{~N} \mathrm{ha}^{-1}, 55 \mathrm{~kg} \mathrm{P} \mathrm{ha}^{-1}$ and $195 \mathrm{~kg} \mathrm{~K} \mathrm{ha}^{-1}[\mathrm{Fe}-$ cenko and Ložek 2000]. The used fertilizer was Duslofert Extra 14- 10-20-7 and the real doses of nutrients applied in the treatment were: $125 \mathrm{~kg}$ $\mathrm{N} \mathrm{ha}^{-1}, 50 \mathrm{~kg} \mathrm{P} \mathrm{ha}^{-1}, 185 \mathrm{~kg} \mathrm{~K} \mathrm{ha}^{-1}$. The dose of nutrients was divided: $2 / 3$ applied into the soil in the spring (bud burst - in March) and 1/3 in flowering (in May).

\section{Soil sampling and analysis}

In this study, the soil samples were taken from all treatments from the depth of $0-30 \mathrm{~cm}$ (topsoil) and $30-60 \mathrm{~cm}$ (subsoil) every spring from 2008 to 2020 (total 13 years). For each sampled zone (included all treatments) four locations were chosen. The sub-samples were mixed to produce an average representative sample, dried at the laboratory temperature, and ground before the analysis. For chemical analysis, the soil samples were sieved to $0.25 \mathrm{~mm}$, and then soil organic carbon content (SOC) by the wet combustion method-oxidation of $\mathrm{SOM}$ by a mixture of $\mathrm{H}_{2} \mathrm{SO}_{4}$ and $\mathrm{K}_{2} \mathrm{Cr}_{2} \mathrm{O}_{7}$ with titration using Mohr's salt was measured [Dziadowiec and Gonet 1999]. The labile carbon content $\left(\mathrm{C}_{\mathrm{L}}\right)$ by the Loginov method [Loginow et al. 1987], content of total nitrogen $\left(\mathrm{N}_{\mathrm{t}}\right)$ by Kjeldahl method [Peterburskij 1963], and content of potentially mineralizable nitrogen $\left(\mathrm{N}_{\text {pot }}\right)$ [Standford and Smith 1978] were analyzed.

The CMI was obtained according to the mathematical procedures used by Blair et al. [1995], which are described below:

$$
C M I=C P I x L I x 100
$$

where: $C P I$ is the carbon pool index and $L I$ is the lability index.

CPI and LI are calculated as follows:

$$
C P I=\frac{C \text { pool in treatment }}{C \text { pool in reference }}
$$

$$
L I=\frac{L \text { in treatment }}{\text { Lin reference }}
$$

where: $L$ refers to the $\mathrm{C}$ lability, calculated as:

$$
L=\frac{C_{L}}{C_{N L}}
$$

and non-labile carbon $\left(\mathrm{C}_{\mathrm{NL}}\right)$ is calculated as:

$$
C_{N L}=S O C-C_{L}
$$

where: SOC is organic carbon content and $C_{L}$ is labile carbon content

From $\mathrm{C}$ indexes according to Blair et al. (1995) mathematically derived indices for nitrogen were done (equations 6-10).

$$
\mathrm{NMI}=\mathrm{NPI} \times \mathrm{NLI}
$$

where: $N M I$ is nitrogen management index, NPI is nitrogen pool index and $N L I$ is the lability nitrogen index.

NPI and NLI are calculated as follows:

$$
\begin{gathered}
N P I=\frac{N \text { pool in treatment }}{N \text { pool in reference }} \\
N L I=\frac{L N \text { in treatment }}{L N \text { in reference }}
\end{gathered}
$$

where: $L N$ refers to the $\mathrm{N}$ lability, calculated as:

$$
L N=\frac{N_{p o t}}{N_{N L}}
$$

Calculation of nitrogen lability $\left(\mathrm{L}_{\mathrm{N}}\right)$

$$
N_{N L}=N_{t}-N_{p o t}
$$

The treatments represented the different soil management practices in vineyard and $G$ was used as a reference because it was assumed that the different soil management involving intensive cultivation and fertilization of the soil would have more rapid changes in $\mathrm{C}$ and $\mathrm{N}$ in SOM comparison with the treatment without the intensive human intervention.

\section{Statistical analysis}

All statistical analyses were performed by using STATGRAPHICS CENTURION XV. I software (Statpoint Technologies, Inc., Warrenton, Virginia, USA). The one-way analysis of variance (ANOVA) and the least significant difference 
(LSD) method was used to compare the treatment means for the soil management practices in the productive vineyard at $p<0.05$. For the expression of SOM parameter dynamics along the time (during 2009-2020) the Mann-Kendall test was used. The correlation matrix was used to assess the relationship between $\mathrm{C}, \mathrm{N}$ their indices as well as forms.

\section{RESULTS AND DISCUSSION}

\section{Effect of soil management practices on standard SOM parameters}

The results showed that the soil fertilization in vineyard had no significant effect on all soil organic matter (SOM) parameters. For example, in tillage treatment $(\mathrm{T})$ the significant decrease in SOC for topsoil compared to other soil management practices in the productive vineyard was determined (Table 1). Soil management practices did not have a statistically significant influence on the SOC for depth of 30-60 cm. The dynamics of SOC, according to the Mann-Kendall test, revealed no trend in all treatments, except $\mathrm{G}$, G+NPK1, and G+NPK3 for topsoil and except G+NPK3 for depth 30-60 cm during the period of 13 years (2008-2020). The content of SOC increased with time in all the above-mentioned treatments. The relative stable trends were observed in values of SOC under T and T+FYM treatments in topsoil and under G, T, T+FYM, G+NPK1 in the subsoil. The changes in SOC content due to the different soil management practices are long-term due to the stability of SOM [Kogel-Knabner et al. 2008]. Saljnikov et al. [2013] stated that up to $60-85 \%$ of SOM is stable and only $10-30 \%$ is the active fraction of SOM, which after an intensive intervention is subject to changes which may be reflected in the change in the content of SOC in the soil. In our case, such an intervention can be tillage treatment $(\mathrm{T})$. Intensive cultivation, especially in the first years after plowing the virgin soil, significantly reduces the $\mathrm{C}$ content [Celette et al. 2005] until its value stabilizes as a result of new soil management. The researchers indicated that SOC decrease is following the conversion of the native ecosystems to agriculture, for example, losses of SOC from the conversion of prairie to agriculture have resulted in 24 to $89 \%$ loss in the North America [Kucharik et al. 2001]. In our case, the $\mathrm{C}$ content was reduced by $26 \%$ compared to the control $(\mathrm{G})$ as a result of intensive cultivation on one hand, but on the other hand, in T+FYM treatment no significant changes in SOC over the 13 years of the experiment were observed. Intensive tillage reduces $\mathrm{C}$ content which is consistent with the claims of several studies [Saha and Ghosh 2013, Mloza-Banda et al. 2016, Novara et al. 2020] and these changes are most significant in topsoil (Table 1). The main cause of the decrease in $\mathrm{C}$ due to tillage is the intensive decomposition and mineralization of SOM caused by turning and aeration of the soil [Novara et al. 2020]. The role of mineral fertilization remains unclear. In some studies, there are presented the results that supported the positive effects on SOC through humus

Table 1. Effect of soil management practices on carbon and nitrogen forms averaged over the studied period (means \pm standard errors).

\begin{tabular}{|c|c|c|c|c|c|c|}
\hline Treatments & SOC, g/kg & $\mathrm{C}_{\mathrm{NL}}, \mathrm{g} / \mathrm{kg}$ & $C_{L}, g / k g$ & $\mathrm{~N}_{\mathrm{t}}, \mathrm{mg} / \mathrm{kg}$ & $\mathrm{N}_{\mathrm{N}}, \mathrm{mg} / \mathrm{kg}$ & $\mathrm{N}_{\mathrm{pot}}, \mathrm{mg} / \mathrm{kg}$ \\
\hline \multicolumn{7}{|c|}{$0-30 \mathrm{~cm}$} \\
\hline G & $19.4 \pm 3.62 b$ & $17.0 \pm 3.05 b$ & $2.45 \pm 0.75 a b$ & $1386 \pm 333 a$ & $1273 \pm 335 a$ & $113 \pm 26 b$ \\
\hline $\mathrm{T}$ & $14.4 \pm 1.92 \mathrm{a}$ & $12.5 \pm 1.84 a$ & $1.88 \pm 0.37 a$ & $1190 \pm 340 a$ & $1111 \pm 348 a$ & $81 \pm 18 a$ \\
\hline T+FYM & $18.5 \pm 2.22 \mathrm{~b}$ & $16.2 \pm 1.88 \mathrm{~b}$ & $2.37 \pm 0.53 a b$ & $1438 \pm 405 a$ & $1321 \pm 204 a$ & $118 \pm 19 b$ \\
\hline G+NPK3 & $18.6 \pm 3.31 b$ & $15.8 \pm 2.59 b$ & $2.78 \pm 0.93 b$ & $1395 \pm 491 a$ & $1277 \pm 307 a$ & $119 \pm 31 b$ \\
\hline G+NPK1 & $19.6 \pm 3.29 b$ & $17.0 \pm 2.72 b$ & $2.61 \pm 0.80 \mathrm{~b}$ & $1291 \pm 289 a$ & $1170 \pm 307 a$ & $122 \pm 26 b$ \\
\hline \multicolumn{7}{|c|}{$30-60 \mathrm{~cm}$} \\
\hline G & $10.8 \pm 1.99 a$ & $9.68 \pm 1.99 a$ & $1.09 \pm 0.27 a$ & $862 \pm 239 a$ & $774 \pm 340 a$ & $88 \pm 26 a b$ \\
\hline $\mathrm{T}$ & $10.2 \pm 2.10 a$ & $8.78 \pm 1.64 a$ & $1.41 \pm 0.30 \mathrm{~b}$ & $911 \pm 279 a$ & $841 \pm 492 a$ & $71 \pm 26 a$ \\
\hline T+FYM & $11.5 \pm 2.30 \mathrm{a}$ & $10.1 \pm 2.33 a$ & $1.39 \pm 0.34 b$ & $838 \pm 325 \pm$ & $857 \pm 238 a$ & $82 \pm 20 a$ \\
\hline G+NPK3 & $11.0 \pm 2.10 \mathrm{a}$ & $9.64 \pm 1.83 a$ & $1.34 \pm 0.30 \mathrm{ab}$ & $872 \pm 354 a$ & $770 \pm 285 a$ & $102 \pm 18 b$ \\
\hline G+NPK1 & $11.2 \pm 2.30 \mathrm{a}$ & $9.85 \pm 2.01 a$ & $1.29 \pm 0.42 a b$ & $871 \pm 234 a$ & $769 \pm 208 a$ & $102 \pm 19 b$ \\
\hline
\end{tabular}

Different letters within lines indicate that treatment means over the sampling dates are significantly different at $p \leq 0.05$ according to the least significant difference (LSD) multiple-range test. 
Table 1. S. Pearson product-moment correlation coefficients and their significance for $\mathrm{C}$, N, and their indices (2008-2020) with dependence on soil management practices in a productive vineyard.

\begin{tabular}{|c|c|c|c|c|c|c|c|c|c|c|c|c|c|c|}
\hline & SOC & $C_{L}$ & $C_{N L}$ & $L$ & LI & $\mathrm{CPI}$ & CMI & $N_{t}$ & $N_{\text {pot }}$ & $N_{N L}$ & $L N$ & $L N I$ & $N P I$ & $N M I$ \\
\hline \multicolumn{15}{|c|}{ G } \\
\hline SOC & & 0.798 & 0.989 & n.s. & n.d. & n.d. & n.d. & n.s. & 0.773 & n.s. & n.s. & n.d. & n.d. & n.d. \\
\hline$C_{L}$ & & & 0.699 & 0.753 & n.d. & n.d. & n.d. & n.s. & n.s. & n.s. & n.s. & n.d. & n.d. & n.d. \\
\hline$C_{N L}$ & & & & n.s. & n.d. & n.d. & n.d. & n.s. & 0.788 & n.s. & n.s. & n.d. & n.d. & n.d. \\
\hline$L$ & & & & & n.d. & n.d. & n.d. & n.s. & n.s. & n.s. & n.s. & n.d. & n.d. & n.d. \\
\hline LI & & & & & & n.d. & n.d. & n.d. & n.d. & n.d. & n.d. & n.d. & n.d. & n.d. \\
\hline $\mathrm{CPI}$ & & & & & & & n.d. & n.d. & n.d. & n.d. & n.d. & n.d. & n.d. & n.d. \\
\hline $\mathrm{CMI}$ & & & & & & & & n.d. & n.d. & n.d. & n.d. & n.d. & n.d. & n.d. \\
\hline$N_{t}$ & & & & & & & & & n.s. & 0.997 & -0.785 & n.d. & n.d. & n.d. \\
\hline$N_{p o t}$ & & & & & & & & & & n.s. & 0.553 & n.d. & n.d. & n.d. \\
\hline$N_{N L}$ & & & & & & & & & & & -0.822 & n.d. & n.d. & n.d. \\
\hline$L N$ & & & & & & & & & & & & n.d. & n.d. & n.d. \\
\hline$L N I$ & & & & & & & & & & & & & n.d. & n.d. \\
\hline$N P I$ & & & & & & & & & & & & & & n.d. \\
\hline $\mathrm{NMI}$ & & & & & & & & & & & & & & \\
\hline \multicolumn{15}{|c|}{$\mathrm{T}$} \\
\hline SOC & & n.s. & 0.982 & n.s. & n.s. & n.s. & n.s. & n.s. & n.s. & n.s. & n.s. & n.s. & n.s. & n.s. \\
\hline$C_{L}$ & & & n.s. & 0.772 & n.s. & n.s. & 0.626 & n.s. & n.s. & n.s. & n.s. & n.s. & n.s. & n.s. \\
\hline$C_{N L}$ & & & & n.s. & n.s. & n.s. & n.s. & n.s. & n.s. & n.s. & n.s. & n.s. & n.s. & n.s. \\
\hline$L$ & & & & & 0.584 & n.s. & n.s. & n.s. & n.s. & n.s. & n.s. & n.s. & n.s. & n.s. \\
\hline $\mathrm{LI}$ & & & & & & n.s. & 0.795 & n.s. & n.s. & n.s. & n.s. & n.s. & n.s. & n.s. \\
\hline $\mathrm{CPI}$ & & & & & & & 0.708 & n.s. & n.s. & n.s. & n.s. & n.s. & n.s. & n.s. \\
\hline $\mathrm{CMI}$ & & & & & & & & n.s. & -0.553 & n.s. & n.s. & n.s. & n.s. & n.s. \\
\hline$N_{t}$ & & & & & & & & & n.s. & 0.999 & -0.820 & n.s. & n.s. & n.s. \\
\hline$N_{p o t}$ & & & & & & & & & & n.s. & 0.780 & 0.616 & n.s. & n.s. \\
\hline$N_{N L}$ & & & & & & & & & & & -0.838 & n.s. & n.s. & n.s. \\
\hline$L N$ & & & & & & & & & & & & 0.570 & n.s. & n.s. \\
\hline LNI & & & & & & & & & & & & & $-0,673$ & 0.934 \\
\hline $\mathrm{NPI}$ & & & & & & & & & & & & & & n.s. \\
\hline $\mathrm{NMI}$ & & & & & & & & & & & & & & \\
\hline \multicolumn{15}{|c|}{$T+F Y M$} \\
\hline SOC & & 0.719 & 0.981 & n.s. & n.s. & n.s. & n.s. & n.s. & n.s. & n.s. & n.s. & n.s. & n.s. & n.s. \\
\hline$C_{L}$ & & & 0.571 & 0.803 & n.s. & n.s. & n.s. & n.s. & n.s. & n.s. & n.s. & n.s. & n.s. & n.s. \\
\hline$C_{N L}$ & & & & n.s. & n.s. & n.s. & n.s. & n.s. & n.s. & n.s. & n.s. & n.s. & n.s. & n.s. \\
\hline$L$ & & & & & n.s. & n.s. & 0.580 & n.s. & n.s. & n.s. & n.s. & n.s. & n.s. & n.s. \\
\hline $\mathrm{LI}$ & & & & & & n.s. & 0.786 & n.s. & n.s. & n.s. & n.s. & n.s. & n.s. & n.s. \\
\hline $\mathrm{CPI}$ & & & & & & & 0.783 & n.s. & n.s. & n.s. & n.s. & n.s. & n.s. & 0.761 \\
\hline $\mathrm{CMI}$ & & & & & & & & n.s. & n.s. & n.s. & n.s. & n.s. & n.s. & n.s. \\
\hline$N_{t}$ & & & & & & & & & n.s. & 0.999 & -0.835 & n.s. & n.s. & n.s. \\
\hline$N_{p o t}$ & & & & & & & & & & n.s. & n.s. & n.s. & n.s. & n.s. \\
\hline$N_{N L}$ & & & & & & & & & & & -0.853 & n.s. & n.s. & n.s. \\
\hline$L N$ & & & & & & & & & & & & n.s. & n.s. & n.s. \\
\hline$L N I$ & & & & & & & & & & & & & -0.760 & 0.881 \\
\hline $\mathrm{NPI}$ & & & & & & & & & & & & & & n.s. \\
\hline $\mathrm{NMI}$ & & & & & & & & & & & & & & \\
\hline
\end{tabular}

stabilization [Gonet 1989], but on the other hand, mainly high amounts of mineral fertilizers might accelerate the mineralization process and therefore diminish SOC [Rutkowska and Pikula 2013]. Total contents of non-labile carbon $\left(\mathrm{C}_{\mathrm{NL}}\right)$ with relation to soil management practices and its dynamics for investigated period follow the results of SOC (Table 1 and 3).

Total nitrogen $\left(\mathrm{N}_{\mathrm{t}}\right)$ in the soil is a relatively stable parameter, as its highest proportion is the 
Table 1. cont.

\begin{tabular}{|c|c|c|c|c|c|c|c|c|c|c|c|c|c|c|}
\hline & SOC & $C_{L}$ & $C_{N L}$ & $L$ & $\mathrm{LI}$ & $C P I$ & CMI & $N_{t}$ & $N_{\rho o t}$ & $N_{N L}$ & $L N$ & $L N I$ & $\mathrm{NPI}$ & NMI \\
\hline \multicolumn{15}{|c|}{$\mathrm{G}+\mathrm{NPK} 3$} \\
\hline SOC & & 0.832 & 0.980 & n.s. & n.s. & n.s. & n.s. & n.s. & 0.657 & n.s. & n.s. & n.s. & n.s. & n.s. \\
\hline$C_{L}$ & & & 0.705 & 0.877 & 0.673 & n.s. & 0.610 & n.s. & 0.679 & n.s. & n.s. & n.s. & n.s. & n.s. \\
\hline$C_{N L}$ & & & & n.s. & n.s. & n.s. & n.s. & n.s. & 0.597 & n.s. & n.s. & n.s. & n.s. & n.s. \\
\hline$L$ & & & & & 0.698 & n.s. & 0.640 & n.s. & n.s. & n.s. & n.s. & n.s. & n.s. & n.s. \\
\hline LI & & & & & & 0.739 & 0.970 & n.s. & 0.614 & n.s. & 0.640 & n.s. & n.s. & 0.647 \\
\hline $\mathrm{CPI}$ & & & & & & & 0.863 & n.s. & n.s. & n.s. & n.s. & 0.568 & n.s. & 0.615 \\
\hline CMI & & & & & & & & n.s. & 0.592 & n.s. & 0.611 & 0.601 & n.s. & 0.687 \\
\hline$N_{t}$ & & & & & & & & & n.s. & 0.995 & -0.756 & -0.713 & 0.712 & n.s. \\
\hline$N_{p o t}$ & & & & & & & & & & n.s. & 0.730 & n.s. & n.s. & 0.826 \\
\hline$N_{N L}$ & & & & & & & & & & & -0.806 & -0.740 & 0.707 & n.s. \\
\hline$L N$ & & & & & & & & & & & & 0.679 & n.s. & 0.729 \\
\hline$L N I$ & & & & & & & & & & & & & -0.753 & 0.827 \\
\hline$N P I$ & & & & & & & & & & & & & & n.s. \\
\hline$N M I$ & & & & & & & & & & & & & & \\
\hline \multicolumn{15}{|c|}{ G+NPK1 } \\
\hline SOC & & 0.773 & 0.982 & n.s. & n.s. & n.s. & n.s. & n.s. & 0.760 & n.s. & n.s. & n.s. & n.s. & n.s. \\
\hline$C_{L}$ & & & 0.642 & 0.830 & n.s. & n.s. & n.s. & n.s. & 0.643 & n.s. & n.s. & n.s. & n.s. & n.s. \\
\hline$C_{N L}$ & & & & n.s. & n.s. & n.s. & n.s. & n.s. & 0.731 & n.s. & n.s. & n.s. & n.s. & n.s. \\
\hline$L$ & & & & & 0.681 & n.s. & 0.702 & n.s. & n.s. & n.s. & n.s. & n.s. & n.s. & n.s. \\
\hline LI & & & & & & n.s. & 0.931 & n.s. & n.s. & n.s. & n.s. & n.s. & n.s. & n.s. \\
\hline $\mathrm{CPI}$ & & & & & & & 0.599 & n.s. & n.s. & n.s. & n.s. & n.s. & n.s. & 0.727 \\
\hline CMI & & & & & & & & n.s. & n.s. & n.s. & n.s. & n.s. & n.s. & n.s. \\
\hline$N_{t}$ & & & & & & & & & n.s. & 0.996 & -0.607 & n.s. & n.s. & n.s. \\
\hline$N_{p o t}$ & & & & & & & & & & n.s. & n.s. & n.s. & n.s. & n.s. \\
\hline$N_{N L}$ & & & & & & & & & & & -0.670 & n.s. & n.s. & n.s. \\
\hline$L N$ & & & & & & & & & & & & n.s. & n.s. & n.s. \\
\hline$L N I$ & & & & & & & & & & & & & n.s. & n.s. \\
\hline$N P I$ & & & & & & & & & & & & & & 0.602 \\
\hline$N M I$ & & & & & & & & & & & & & & \\
\hline
\end{tabular}

n.d. - no detected; n.s. - non-significant.

organic $\mathrm{N}$ and only a low proportion of it is liable to a transformation. The differences in $\mathrm{N}_{t}$ content in the soil may be due to the soil management practices as intensive cultivation when no biomass remains on the surface, incorporation of FYM by biochemical stabilization of SOM, but also more intensive mineralization on one hand or due to higher biomass production under mineral fertilization on the other [Saljnikov et al. 2013]. The analysis of variance showed that $\mathrm{N}_{\mathrm{t}}$ and non-labile nitrogen $\left(\mathrm{N}_{\mathrm{NL}}\right)$ for both depths were not statistically different among treatments. However, there was observed a different trend in accumulating $\mathrm{N}$ (Table 1). Also, the results of the Mann-Kendall test showed no robust changes in $\mathrm{N}_{\mathrm{t}}$ as well as in $\mathrm{N}_{\mathrm{NL}}$ contents in the individual treatments (Table 3 ).

Labile carbon $\left(\mathrm{C}_{\mathrm{L}}\right)$ [Blair et al. 1995, Conteh et al. 1999] and potentially mineralizable nitrogen
$\left(\mathrm{N}_{\text {pot }}\right)$ [Saljnikov-Karbozova et al. 2004] are highly sensitive indicators of SOM. At 0-30 (topsoil) and 30-60 (subsoil) $\mathrm{cm}$ depths, the $\mathrm{C}_{\mathrm{L}}$ fluctuated from 1.88 to $2.79 \mathrm{~g} \mathrm{~kg}^{-1}$ and from 1.10 to $1.41 \mathrm{~g}$ $\mathrm{kg}^{-1}$ respectively, and the soil management practices in the vineyard have the statistically significant influence on $C_{L}$ (Table 1). A higher $C_{L}$ content was in $\mathrm{G}+\mathrm{NPK} 3(2.78 \pm 0.9)$ than follows: G+NPK1 (2.61 \pm 0.8$), \quad$ G $(2.45 \pm 0.7), \quad$ T+FYM (2.37 \pm 0.5$)$, and in $\mathrm{T}$ treatment (1.88 \pm 0.4$)$ for topsoil. For subsoil, a different trend was observed. The content of $\mathrm{C}_{\mathrm{L}}$ was higher by $29,28,23$, and $19 \%$ in the T, T+FYM, G+NPK3, and G+NPK1, respectively, compared to $\mathrm{G}$. In the $\mathrm{T}$ treatment, a lower $\mathrm{C}_{\mathrm{L}}$ content in the topsoil indicated a smaller amount of SOM, which can mineralize. Also, the results of the Mann-Kendall test showed a significant decrease in $\mathrm{C}_{\mathrm{L}}$ under $\mathrm{T}$ treatment for topsoil (Table 3). Higher $\mathrm{C}_{\mathrm{L}}$ content can be a result of the 
Table 2. Effect of soil management practices on carbon and nitrogen indices averaged over the studied period (means \pm standard errors).

\begin{tabular}{|c|c|c|c|c|c|c|c|c|}
\hline Treatments & $\mathrm{L}$ & $\mathrm{LI}$ & $\mathrm{CMI}$ & $\mathrm{CPI}$ & LN & LNI & NMI & NPI \\
\hline \multicolumn{9}{|c|}{$0-30 \mathrm{~cm}$} \\
\hline G & $0.144 \pm 0.030 \mathrm{a}$ & & & & $0.088 \pm 0.33 a$ & & & \\
\hline $\mathrm{T}$ & $0.152 \pm 0.033 a b$ & $1.13 \pm 0.25 a$ & $88 \pm 31 a$ & $0.767 \pm 0.17 a$ & $0.073 \pm 0.027 a$ & $0.909 \pm 0.45 a$ & $74 \pm 27 a$ & $0.872 \pm 0.16 a$ \\
\hline T+FYM & $0.147 \pm 0.026 a b$ & $1.04 \pm 0.19 a$ & $103 \pm 27 a b$ & $0.981 \pm 0.18 b$ & $0.087 \pm 0.024 a$ & $1.056 \pm 0.33 a$ & $107 \pm 20 b$ & $1.048 \pm 0.17 a$ \\
\hline $\mathrm{G}+\mathrm{NPK} 3$ & $0.173 \pm 0.041 b$ & $1.24 \pm 0.34 b$ & $123 \pm 47 b$ & $0.969 \pm 0.13 b$ & $0.099 \pm 0.058 a$ & $1.095 \pm 0.48 a$ & $101 \pm 18 b$ & $1.017 \pm 0.32 \mathrm{a}$ \\
\hline $\mathrm{G}+\mathrm{NPK} 1$ & $0.153 \pm 0.036 a b$ & $1.09 \pm 0.31 \mathrm{a}$ & $113 \pm 39 a b$ & $1.028 \pm 0.16 \mathrm{~b}$ & $0.097 \pm 0.025 a$ & $0.154 \pm 0.19 a$ & $109 \pm 22 b$ & $0.956 \pm 0.18 a$ \\
\hline \multicolumn{9}{|c|}{$30-60 \mathrm{~cm}$} \\
\hline G & $0.116 \pm 0.036 a$ & & & & $0.118 \pm 0.054 a$ & & & \\
\hline $\mathrm{T}$ & $0.163 \pm 0.036 b$ & $1.39 \pm 0.35 b$ & $133 \pm 33 a$ & $0.966 \pm 0.17 a$ & $0.097 \pm 0.056 a$ & $0.805 \pm 0.30 a$ & $82 \pm 24 a$ & $1.081 \pm 0.29 a$ \\
\hline$T+F Y M$ & $0.146 \pm 0.054 a b$ & $1.26 \pm 0.33 a b$ & $130 \pm 38 a$ & $1.047 \pm 0.22 a$ & $0.103 \pm 0.048 a$ & $0.876 \pm 0.32 a$ & $97 \pm 28 \mathrm{ab}$ & $1.127 \pm 0.25 a$ \\
\hline $\mathrm{G}+\mathrm{NPK} 3$ & $0.140 \pm 0.024 a b$ & $1.27 \pm 0.27 a b$ & $130 \pm 31 a$ & $1.027 \pm 0.11 a$ & $0.131 \pm 0.041 a$ & $1.209 \pm 0.35 b$ & $123 \pm 31 c$ & $1.040 \pm 0.16 a$ \\
\hline $\mathrm{G}+\mathrm{NPK} 1$ & $0.132 \pm 0.033 a$ & $1.16 \pm 0.17 a$ & $120 \pm 22 a$ & $1.048 \pm 0.17 a$ & $0.129 \pm 0.038 a$ & $1.201 \pm 0.34 b$ & $122 \pm 20 b c$ & $1.044 \pm 0.20 \mathrm{a}$ \\
\hline
\end{tabular}

Different letters within lines indicate that treatment means over the sampling dates are significantly different at $p \leq 0.05$ according to the least significant difference (LSD) multiple-range test.

application of FYM in T+FYM treatment and a higher roots mass in $\mathrm{G}, \mathrm{G}+\mathrm{NPK} 1$, and $\mathrm{G}+\mathrm{NPK} 3$ treatments. In the subsoil, higher content of $\mathrm{C}_{\mathrm{L}}$ under T, and T+FYM treatments can be explained by mixing of the upper layer with lower layers and as a result of plowing of FYM to the depth. The rhizodeposition is the major source of labile carbon in the soil. The unsteady rhizodeposition during the year as well as microbial activity cause the fluctuation of $\mathrm{C}_{\mathrm{L}}$ production in the soil (Table 3 ). For subsoil stable trends and for 0-30 $\mathrm{cm}$ also, the stable trend of in $\mathrm{C}_{\mathrm{L}}$ dynamic except $\mathrm{G}+\mathrm{NPK} 1$ were observed during the period of 13 years. In spite of the fact that the potentially mineralizable nitrogen $\left(\mathrm{N}_{\text {pot }}\right)$ represents only a small proportion in the soil out of the total nitrogen about $6.5-11.7 \%$ in this study, it has a substantial impact from the aspect of plants nutrition, microbial processes, and SOM turnover. However, the fundamental fact is that even this low quantity is liable to the considerable seasonal changes [Ondrišík et al., 2009, Ondrišík 2013], which are influenced apart from the climatic facts [Malhi et al. 2006] also by the soil management including soil fertilization [Vaněk et al. 2013, Šimanský et al. 2018] which confirmed the results

Table 3. Dynamics of $\mathrm{C}$ in different soil management practices over the studied period according to the results of the Mann-Kendall test

\begin{tabular}{|c|c|c|c|c|c|c|c|}
\hline Treatments & $\mathrm{SOC}$ & $\mathrm{C}_{\perp}$ & $\mathrm{C}_{\mathrm{NL}}$ & $\mathrm{L}$ & LI & $\mathrm{CMI}$ & $\mathrm{CPI}$ \\
\hline \multicolumn{8}{|c|}{$0-30 \mathrm{~cm}$} \\
\hline G & Increasing & Stable/No trend & Increasing & $\begin{array}{c}\text { Stable/No } \\
\text { trend }\end{array}$ & $\begin{array}{l}\text { Stable/No } \\
\text { trend }\end{array}$ & Decreasing & Decreasing \\
\hline $\mathrm{T}$ & $\begin{array}{l}\text { Stable/No } \\
\text { trend }\end{array}$ & Decreasing & $\begin{array}{c}\text { Stable/No } \\
\text { trend }\end{array}$ & $\begin{array}{c}\text { Stable/No } \\
\text { trend }\end{array}$ & $\begin{array}{c}\text { Stable/No } \\
\text { trend }\end{array}$ & Decreasing & Decreasing \\
\hline$T+F Y M$ & $\begin{array}{c}\text { Stable/No } \\
\text { trend }\end{array}$ & Stable/No trend & Increasing & Decreasing & $\begin{array}{c}\text { Stable/No } \\
\text { trend }\end{array}$ & $\begin{array}{c}\text { Stable/No } \\
\text { trend }\end{array}$ & $\begin{array}{c}\text { Stable/No } \\
\text { trend }\end{array}$ \\
\hline G+NPK3 & Increasing & Stable/No trend & Increasing & $\begin{array}{c}\text { Stable/No } \\
\text { trend }\end{array}$ & $\begin{array}{c}\text { Stable/No } \\
\text { trend }\end{array}$ & $\begin{array}{c}\text { Stable/No } \\
\text { trend }\end{array}$ & $\begin{array}{c}\text { Stable/No } \\
\text { trend }\end{array}$ \\
\hline G+NPK1 & Increasing & Increasing & Increasing & $\begin{array}{c}\text { Stable/No } \\
\text { trend }\end{array}$ & $\begin{array}{c}\text { Stable/No } \\
\text { trend }\end{array}$ & $\begin{array}{c}\text { Stable/No } \\
\text { trend }\end{array}$ & $\begin{array}{c}\text { Stable/No } \\
\text { trend }\end{array}$ \\
\hline \multicolumn{8}{|c|}{$30-60 \mathrm{~cm}$} \\
\hline G & $\begin{array}{c}\text { Stable/No } \\
\text { trend }\end{array}$ & Stable/No trend & $\begin{array}{c}\text { Stable/No } \\
\text { trend }\end{array}$ & Decreasing & $\begin{array}{c}\text { Stable/No } \\
\text { trend }\end{array}$ & $\begin{array}{c}\text { Stable/No } \\
\text { trend }\end{array}$ & $\begin{array}{c}\text { Stable/No } \\
\text { trend }\end{array}$ \\
\hline $\mathrm{T}$ & $\begin{array}{c}\text { Stable/No } \\
\text { trend }\end{array}$ & Stable/No trend & $\begin{array}{c}\text { Stable/No } \\
\text { trend }\end{array}$ & $\begin{array}{c}\text { Stable/No } \\
\text { trend }\end{array}$ & $\begin{array}{c}\text { Stable/No } \\
\text { trend }\end{array}$ & $\begin{array}{c}\text { Stable/No } \\
\text { trend }\end{array}$ & $\begin{array}{c}\text { Stable/No } \\
\text { trend }\end{array}$ \\
\hline$T+F Y M$ & $\begin{array}{c}\text { Stable/No } \\
\text { trend }\end{array}$ & Stable/No trend & $\begin{array}{c}\text { Stable/No } \\
\text { trend }\end{array}$ & Decreasing & $\begin{array}{c}\text { Stable/No } \\
\text { trend }\end{array}$ & $\begin{array}{c}\text { Stable/No } \\
\text { trend }\end{array}$ & $\begin{array}{c}\text { Stable/No } \\
\text { trend }\end{array}$ \\
\hline G+NPK3 & Increasing & Stable/No trend & Increasing & $\begin{array}{c}\text { Stable/No } \\
\text { trend }\end{array}$ & Increasing & Increasing & $\begin{array}{c}\text { Stable/No } \\
\text { trend }\end{array}$ \\
\hline G+NPK1 & $\begin{array}{c}\text { Stable/No } \\
\text { trend }\end{array}$ & Stable/No trend & $\begin{array}{c}\text { Stable/No } \\
\text { trend }\end{array}$ & $\begin{array}{c}\text { Stable/No } \\
\text { trend }\end{array}$ & $\begin{array}{c}\text { Stable/No } \\
\text { trend }\end{array}$ & $\begin{array}{c}\text { Stable/No } \\
\text { trend }\end{array}$ & $\begin{array}{c}\text { Stable/No } \\
\text { trend }\end{array}$ \\
\hline
\end{tabular}


of this study (Table 1). The highest content of $\mathrm{N}_{\text {pot }}$ was recorded in G+NPK1, G+NPK3 and T+FYM treatments (fertilized treatments) followed by $\mathrm{G}$ and $\mathrm{T}$ treatments for topsoil. The similar trend in $\mathrm{N}_{\text {pot }}$ for $30-60 \mathrm{~cm}$ was also recorded. The application of fertilizers might lead to the accelerated mineralization of SOM [Saljnikov et al. 2013] which is reflected in a higher $\mathrm{N}_{\text {pot }}$ contents. The content of $\mathrm{N}_{\text {pot }}$ increased with time in $\mathrm{G}, \mathrm{T}+\mathrm{FYM}$, $\mathrm{G}+\mathrm{NPK} 1$, and G+NPK3 treatments, while a stable trend was found in $\mathrm{T}$ treatment for topsoil. For subsoil, $\mathrm{N}_{\text {pot }}$ increased only in $\mathrm{T}+\mathrm{FYM}$, while in other treatments no trends were observed during the 2009-2020 (results evaluated by MannKendal test).

\section{Effect of soil management practices based on $\mathrm{C}$ and $\mathrm{N}$ management indices}

The changes in SOM and their dynamics for the investigated period for both depths were evaluated on the basis of carbon indices according to Blair et al. [1995] because they more sensitively react to the changes in soil management practices and what is important in sort terms. The values of carbon lability $\left(\mathrm{L}_{\mathrm{C}}\right)$ were statistically significantly affected by the soil management practices in the productive vineyard along both depths. In topsoil, $\mathrm{L}_{\mathrm{C}}$ increased after a higher level of mineral fertilization, while in subsoil after intensive cultivation both compared to $\mathrm{G}$. The values of $\mathrm{L}_{\mathrm{C}}$ corresponded with LI values (Table 2) but the dynamic has been different (Table 4). Higher values of $\mathrm{L}_{\mathrm{C}}$, as well as LI indicate that SOM is rapidly degradable by micro-organisms on one hand, and lower values of LI indicate SOM is a greater stability and resistance to microbial degradation on the other [Szombathová 1999, Viera et al. 2007, Bendi et al. 2015]. The highest LI values were found in G+NPK3 and T for depth $0-30$ and $30-60 \mathrm{~cm}$, respectively, compared to $\mathrm{G}$ treatment. The LI dynamics based on the Mann-Kendal test showed no changes for topsoil but increasing in LI values in G+NPK3 for subsoil for the investigated period. Thus, higher rates of mineral fertilizers, as well as intensive cultivation between vine rows increased the amount of less stable forms of SOM, mainly by the promotion of root exudates excretion and the amount of grasses' residues, or through the decay of stable SOM due to high doses of NPK application. Fröberg et al. [2013], as well as Tong et al. [2014] also reported the impacts of mineral fertilizers and the effect of manure on the mineralization of SOM. The loss of $\mathrm{C}$ from the soil with a large carbon pool is of less consequence than the loss of the same amount of $\mathrm{C}$ from the soil already depleted of $\mathrm{C}$ or which started with a smaller total C pool. Similarly, the more soil has been depleted of carbon the more difficult it is to rehabilitate Blair et al. [1995]. The values of CPI for depth of 0-30 cm decreased in the following order: G+NPK1 > $\mathrm{T}+\mathrm{FYM}>\mathrm{G}+\mathrm{NPK} 3>\mathrm{T}$. The results showed that SOM is more intensively degraded due to the intensive cultivation what is confirmed also by the result of the Mann-Kendall test (Table 4). On the other hand, the most significant accumulation of SOM can be observed after the application of rational doses of mineral fertilizer without intensive cultivation of vine rows (G+NPK1), in addition, the CPI values showed a stable trend. No changes in CPI for subsoil were observed (Table 2 and 4). Based on CMI values, intensive changes in the SOM due to the soil management practices and more carbon released from the soil stock were observed in T treatment (Table 2) and these changes were evident during the whole period because CMI values decreased with time for topsoil (Table 4). The highest accumulation of carbon and decomposable organic matter occurred in G+NPK3 (Table 2), however, CMI dynamic with the time was stable.

According to Blair et al. [1995] we calculated the carbon indices (Table 2) and from which nitrogen indices were derived as well, such as: nitrogen lability $\left(\mathrm{L}_{\mathrm{N}}\right)$, nitrogen lability index (NLI), nitrogen pool index (NPI), and nitrogen management index (NMI), which could be considered as their equivalents with carbon [Blair et al. 1995, Contheh et al. 1999, Szombathová 1999, Viera et al. 2007, Bendi et al. 2015, Šimanský and Polláková 2016, Šimanský et al. 2018] to be more sensitive indicators of the soil organic substance. On the whole, the values $\mathrm{L}_{\mathrm{N}}$ were no changed along with the soil management practices for both depths. The Mann-Kendall test showed stable trends in $\mathrm{L}_{\mathrm{N}}$ for all treatments. The soil management practices in the productive vineyard did not have a significant effect on NLI for topsoil, but the application of mineral fertilization in $3^{\text {rd }}(\mathrm{G}+\mathrm{NPK} 3)$ and $1^{\text {st }}$ (G+NPK1) intensity for productive vineyards had a statistically significant effect on the increase of NLI for subsoil (Table 2). For both depths, the stable trends in NLI during the investigated period were observed (Table 4). The effect of soil management practices in the productive vineyard 
Table 4. Dynamics of $\mathrm{N}$ in different soil management practices over the studied period according to the results of the Mann-Kendall test

\begin{tabular}{|c|c|c|c|c|c|c|c|}
\hline Treatments & $\mathrm{Nt}$ & $\mathrm{N}_{\text {pot }}$ & $\mathrm{N}_{\mathrm{NL}}$ & LN & $\mathrm{NLI}$ & NMI & NPI \\
\hline \multicolumn{8}{|c|}{$0-30 \mathrm{~cm}$} \\
\hline G & $\begin{array}{c}\text { Stable/ } \\
\text { No trend }\end{array}$ & Increasing & $\begin{array}{c}\text { Stable/ } \\
\text { No trend }\end{array}$ & $\begin{array}{c}\text { Stable/ } \\
\text { No trend }\end{array}$ & & & \\
\hline $\mathrm{T}$ & $\begin{array}{c}\text { Stable/ } \\
\text { No trend }\end{array}$ & $\begin{array}{l}\text { Stable/ } \\
\text { No trend }\end{array}$ & $\begin{array}{c}\text { Stable/ } \\
\text { No trend }\end{array}$ & $\begin{array}{l}\text { Stable/ } \\
\text { No trend }\end{array}$ & $\begin{array}{c}\text { Stable/ } \\
\text { No trend }\end{array}$ & $\begin{array}{c}\text { Stable/ } \\
\text { No trend }\end{array}$ & Decreasing \\
\hline $\mathrm{T}+\mathrm{FYM}$ & $\begin{array}{c}\text { Stable/ } \\
\text { No trend }\end{array}$ & Increasing & $\begin{array}{c}\text { Stable/ } \\
\text { No trend }\end{array}$ & $\begin{array}{c}\text { Stable/ } \\
\text { No trend }\end{array}$ & $\begin{array}{c}\text { Stable/ } \\
\text { No trend }\end{array}$ & Decreasing & $\begin{array}{c}\text { Stable/ } \\
\text { No trend }\end{array}$ \\
\hline G+NPK3 & $\begin{array}{c}\text { Stable/ } \\
\text { No trend }\end{array}$ & Increasing & $\begin{array}{c}\text { Stable/ } \\
\text { No trend }\end{array}$ & Increasing & $\begin{array}{c}\text { Stable/ } \\
\text { No trend }\end{array}$ & $\begin{array}{c}\text { Stable/ } \\
\text { No trend }\end{array}$ & $\begin{array}{c}\text { Stable/ } \\
\text { No trend }\end{array}$ \\
\hline G+NPK1 & $\begin{array}{c}\text { Stable/ } \\
\text { No trend }\end{array}$ & Increasing & $\begin{array}{c}\text { Stable/ } \\
\text { No trend }\end{array}$ & $\begin{array}{c}\text { Stable/ } \\
\text { No trend }\end{array}$ & $\begin{array}{c}\text { Stable/ } \\
\text { No trend }\end{array}$ & $\begin{array}{c}\text { Stable/ } \\
\text { No trend }\end{array}$ & $\begin{array}{c}\text { Stable/ } \\
\text { No trend }\end{array}$ \\
\hline \multicolumn{8}{|c|}{$30-60 \mathrm{~cm}$} \\
\hline$G$ & $\begin{array}{c}\text { Stable/ } \\
\text { No trend }\end{array}$ & $\begin{array}{c}\text { Stable/ } \\
\text { No trend }\end{array}$ & $\begin{array}{c}\text { Stable/ } \\
\text { No trend }\end{array}$ & $\begin{array}{c}\text { Stable/ } \\
\text { No trend }\end{array}$ & & & \\
\hline $\mathrm{T}$ & $\begin{array}{c}\text { Stable/ } \\
\text { No trend }\end{array}$ & $\begin{array}{c}\text { Stable/ } \\
\text { No trend }\end{array}$ & $\begin{array}{c}\text { Stable/ } \\
\text { No trend }\end{array}$ & $\begin{array}{c}\text { Stable/ } \\
\text { No trend }\end{array}$ & $\begin{array}{c}\text { Stable/ } \\
\text { No trend }\end{array}$ & $\begin{array}{c}\text { Stable/ } \\
\text { No trend }\end{array}$ & $\begin{array}{c}\text { Stable/ } \\
\text { No trend }\end{array}$ \\
\hline $\mathrm{T}+\mathrm{FYM}$ & $\begin{array}{c}\text { Stable/ } \\
\text { No trend }\end{array}$ & Increasing & $\begin{array}{c}\text { Stable/ } \\
\text { No trend }\end{array}$ & $\begin{array}{c}\text { Stable/ } \\
\text { No trend }\end{array}$ & $\begin{array}{c}\text { Stable/ } \\
\text { No trend }\end{array}$ & Increasing & $\begin{array}{c}\text { Stable/ } \\
\text { No trend }\end{array}$ \\
\hline G+NPK3 & $\begin{array}{c}\text { Stable/ } \\
\text { No trend }\end{array}$ & $\begin{array}{c}\text { Stable/ } \\
\text { No trend }\end{array}$ & $\begin{array}{c}\text { Stable/ } \\
\text { No trend }\end{array}$ & $\begin{array}{c}\text { Stable/ } \\
\text { No trend }\end{array}$ & $\begin{array}{c}\text { Stable/ } \\
\text { No trend }\end{array}$ & $\begin{array}{c}\text { Stable/ } \\
\text { No trend }\end{array}$ & $\begin{array}{c}\text { Stable/ } \\
\text { No trend }\end{array}$ \\
\hline G+NPK1 & $\begin{array}{c}\text { Stable/ } \\
\text { No trend }\end{array}$ & $\begin{array}{c}\text { Stable/ } \\
\text { No trend }\end{array}$ & $\begin{array}{c}\text { Stable/ } \\
\text { No trend }\end{array}$ & $\begin{array}{c}\text { Stable/ } \\
\text { No trend }\end{array}$ & $\begin{array}{c}\text { Stable/ } \\
\text { No trend }\end{array}$ & $\begin{array}{c}\text { Stable/ } \\
\text { No trend }\end{array}$ & $\begin{array}{c}\text { Stable/ } \\
\text { No trend }\end{array}$ \\
\hline
\end{tabular}

was evaluated also by the calculated values NMI. Lower values NMI indicate more intensive changes of the content of organic substance as a result of the soil management and a higher quantity of nitrogen released from soil. The incorporation of FYM, and application $1^{\text {st }}$ and $3^{\text {rd }}$ intensity of NPK for vineyard increased values of NMI by 45,47 , and $36 \%$ respectively, compared to the intensive tilled treatment for topsoil. During the period of 13 years, the dynamics of changes in NMI were stable under T, G+NPK3, and G+NPK1, but on the other hand, the decreasing trend was observed in T+FYM treatment. Overall, NMI values significantly increased after mineral fertilization (intensively in NPK3 than in NPK1) compared to $\mathrm{T}$ treatment for subsoil (Table 2). NMI dynamics with the time was stable, except T+FYM. In this treatment, the increasing trend in NMI values with time was observed (Table 4). From the viewpoint of sustainable agriculture, the use of mineral fertilizers alone without the application of manures is not the correct direction in the soil management [Plaza-Bonilla et al. 2015], which our finding did not confirm. Based on NMI values it is evident that the highest $\mathrm{N}$ accumulation in SOM was determined in G+NPK1 for topsoil and in G+NPK3 for subsoil. The mentioned effect can be supported by a combination of NPK application to grassland between vine rows, microbial activity, production of higher above and groundmass. The values of NPI were not affected by the soil management practices in the productive vineyard for both depths; however, differences between the treatments were observed (Table 2). The highest values of the NPI were detected as a result of farmyard manure application and mineral fertilization in $3^{\text {rd }}$ intensity for vineyards for topsoil and as a result of the intensive cultivation between vine rows as well as plowing of FYM for subsoil. The results point to the fact that SOM is degraded especially due to the intensive soil cultivation [Khorramdel et al. 2013, Obia et al. 2016], and as a result of the application of mineral fertilizers [Šimanský et al. 2019]. The results obtained in this study showed that the greatest enrichment in $\mathrm{N}$ occurred in the T+FYM treatment for topsoil, the depletion in $\mathrm{N}$ in G+NPK3 for subsoil. In $\mathrm{T}$ treatment, the average NPI was lower than 1 , which means the decreasing trend of nitrogen in SOM for topsoil, which confirmed the results of NPI dynamics with the time in this treatment (Table 4).

\section{Suitability of $\mathrm{C}$ and $\mathrm{N}$ management indices for the evaluation of SOM status under the different soil management practices}

Soil carbon [Blair et al. 1995, Szombathová 1999, Belay-Tedla et al. 2009] and nitrogen [Kováćik and Ryant, 2019] pools can be divided into a labile pool and a recalcitrant fraction - both pools were determined in this study. Between 
$\mathrm{C}$ and $\mathrm{N}$ and their forms there the narrow relations exist, which partially confirmed the results in Table 1S. These relationships depend on the soil management practices. The content of SOC positive correlated with stabile $\mathrm{C}\left(\mathrm{C}_{\mathrm{NL}}\right)$ form along with all the soil management practices in the productive vineyard. The higher content of SOC resulted in higher $\mathrm{C}_{\mathrm{L}}$ and $\mathrm{N}_{\text {pot }}$ contents in the fertilized treatments $(\mathrm{T}+\mathrm{FYM}, \mathrm{G}+\mathrm{NPK} 3$, and $\mathrm{G}+\mathrm{NPK} 1$ ). In $\mathrm{G}$ and $\mathrm{T}$ treatments, between $\mathrm{C}$ and $\mathrm{N}$ indices, no significant correlation was determined. Along with the fertilized treatments, the values of CPI positively correlated with NMI - in other words: a higher accumulation of $\mathrm{C}$ resulted in the intensive changes in the SOM due to fertilization in the productive vineyard, and more nitrogen released from the soil stock were observed. The changes in SOM are the results of soil management practices which is in line with several authors [Szombathová 1999, Fröberg et al. 2013, Tong et al. 2014, Plaza-Bonilla et al. 2015, Šimanský et al. 2019, Novara et al. 2020].

\section{CONCLUSION}

It is evident from the results that the processes of SOM transformation in the context of changes in the content of $\mathrm{C}$ and $\mathrm{N}$ were significantly different under the different soil management in the vineyard, but also the depth of the soil profile. Due to the different soil management in the productive vineyard, more changes were observed in $\mathrm{C}$ than $\mathrm{N}$ in SOM. Thus, the parameters of $\mathrm{C}$ were more justified for the evaluation of changes in the SOM due to the management of the productive vineyard compared to the $\mathrm{N}$ indices. More significant changes were observed in the topsoil than the subsoil.

Overall, the intensive tillage system between the vine rows clearly appeared to be a poor soil management in the context of changes in SOM. The intensive cultivation reduces $\mathrm{C}$ and its accumulation in topsoil on the one hand, but increases the lability of SOM in the subsoil on the other. The intensive mineral fertilization at high rates significantly increases the accumulation of $\mathrm{C}$ in SOM in topsoil.

\section{Acknowledgments}

The research was partially supported by the Cultural and Educational Grant Agency MŠVVaŠ
SR (KEGA) project no. 013SPU-4/2021 „Development of Pedological Terminology of Slovak and English Equivalents and Their Applicability in Scientific-Pedagogical Process", and the Operational Program Integrated Infrastructure within the project „Scientific support of climate change adaptation in agriculture and mitigation of soil degradation" (ITMS2014+ 313011W580)

\section{REFERENCES}

1. Belay-Tedla A., Zhou X., Su B., Wan S., Luo Y. 2009. Labile, recalcitrant, and microbial carbon and nitrogen pools of a tallgrass prairie soil in the US Great Plains subjected to experimental warming and clipping. Soil Biology \& Biochemistry, 41, 110-116.

2. Bendi D.K., Brar K., Toor A.S., Sharma S. 2015. Sensitivity of labile soil organic carbon pools to long-term fertilizer, straw and manure management in rice-wheat system. Pedosphere, 25, 534-545.

3. Blair G.J., Lefroy R.D.B., Lisle L. 1995. Soil carbon fractions based on their degree of oxidation, and the development of a carbon management index for agricultural system. Australian Journal of Agricultural Research, 46, 1459-1466.

4. Celette F, Gaudin R, Gary C. 2008. Spatial and temporal changes to the water regime of a Mediterranean vineyard due to the adoption of cover cropping. European Journal of Agronomy, 29,153-162.

5. Celette F., Wery J., Chantelot E., Celette J., Gary C. 2005. Belowground interactions in a vine (Vitis vinifera L.)-tall fescue (Festuca arundinacea Shreb.) intercropping system: water relations and growth. Plant and Soil, 276, 205-217.

6. Conteh A., Blair G.J., Lefroy, R.D.B., Whitbread A. 1999. Labile organic carbon determined by permangante oxidation and its relationships to other measurements of soil organic carbon. Humic Substances in the Environment, 1, 3-15.

7. de Moraes Sá J.C., Potma Gonçalves D.R., Ferreira L.A., Mishra U., Inagaki T.M., Ferreira Furlan F.J., Moro R.S., Floriani N., Briedis C., de Oliveira Ferreira A. 2018. Soil carbon fractions and biological activity based indices can be used to study the impact of land management and ecological successions. Ecological Indicators, 84, 96-105.

8. Dziadowiec H., Gonet S.S. 1999. Estimation of soil organic carbon by Tiurin's method. Methodical guide-book for soil organic matter studies (in polish). 120, 7-8.

9. European Commission. Healthy soils - new EU soil strategy -> Roadmap - Ares (2020)6391319 -> Download. Available online: https://ec.europa. 
eu/info/law/better-regulation/have-your-say/ initiatives/12634-New-EU-Soil-Strategy-healthysoil-for-a-healthy-life (accessed on 9 January 2021).

10. Fecenko J., Ložek O. 2000. Nutrition and fertilization of field crops. SAU, Nitra. pp. 387. (in Slovak).

11. Fröberg M., Grip H., Tipping E., Svensson M., Stromgren M., Kleja D.B. 2013. Long-term effects of experimental fertilization and soil warming on dissolved organic matter leaching from a spruce forest in Northern Sweden. Geoderma, 200-201, 172-179.

12. Garousi F., Shan Z., Ni K., Yang H., Shan J., Cao J., Jiang Z., Yang J., Zhu T., Müller C. 2021. Decreased inorganic $\mathrm{N}$ supply capacity and turnover in calcareous soil under degraded rubber plantation in the tropical karst region. Geoderma, 381, 114754.

13. Gonet S.S. 1989. Wlaściwości kwasów humusowych w warunkach zróznicowanego nawozenia. ATR Bydgoszcz, Rozprawy, 33, 4-55.

14. Hernandez-Soriano M.C. 2013. Soil processes and current trends in quality assessment. IntechOpen, Rijeka, Croatia. pp. 433.

15. IUSS Working Group WRB, 2015. World reference base for soil resources 2014, update 2015. International soil classification system for naming soils and creating legends for soil maps. In: World Soil Resources Reports No. 106. FAO, Rome.

16. Khorramdel S., Koocheki A., Mahallati M.N., Khorasani R., Ghorbani R. 2013. Evaluation of carbon sequestration potential in corn fields with different management systems. Soil \& Tillage Research, 133, $25-31$.

17. Kobza J., Barančíková G., Makovníková J., Pálka B., Styk J., Širáň M. 2017. Current state and development of land degradation processes based on soil monitoring in Slovakia. Agriculture (Pol'nohospodárstvo), 63(2), 74-85.

18. Kogel-Knabner I., Ekschitt K., Flessa H., Guggenberger G., Matzner E., Marschener B., Von Lützow M. 2008. An intergrative approach of organic matter stabilization in temperate soils: Linking chemistry, physics and biology. Journal of Plant Nutrition and Soil Science, 171(1), 5-13.

19. Komatsuzaki M., Ohta, H. 2007. Soil management proactices for sustainable agroecosystems. Technical Raport. Sustainability Science, 2, 103-120.

20. Kováčik P., Ryant P. 2019. Agrochemistry (principles and practice). SUA, Nitra. pp.358. (in Slovak).

21. Kucharik C.J., Brye K.R., Norman J.M., Foley J.A., Gower S.T., Bundy L.G. 2001. Measurement and modelling of carbon and nitrogen cycling in agroecosystems of southern Wisconsin: Potential for SOC sequestration during the next 50 years. Ecosystems, 4(3), 237-258.

22. Łoginow W., Wisniewski W., Gonet S.S., Ciescinska B. 1987. Fractionation of organic carbon based on susceptibility to oxidation. Polish Journal of Soil Science, 20, 47-52.

23. Ložek O., Bugáňová S., Šimanský V. 2017. The influence of macro and micronutrients on the yield and quality of grapes in the Malokarpatska winegrowing region. SPU, Nitra pp. 85. (in Slovak).

24. Malhi S.S., Lemke R.L., Wang Z., Farrell R., Chhabra B.S. 2006. Tillage, nitrogen and crop residue effects on crop yield and nutrient uptake, soil quality and greenhouse gas emissions. Soil and Tillage Research, 90(1-2), 171-183.

25. Mloza-Banda H.R., Makwiza C.N., Mloza-Banda M.L. 2016. Soil properties after conversion to conservation agriculture from ridge tillage in Southern Malawi. Journal of Arid Environments, 127, 7-16.

26. Novara A., Favara V., Novara A., Francesca N., Santangelo T., Columba P., Chironi S., Ingrassia M., Gristina L. 2020. Soil carbon budget account for the sustainability improvement of a mediterranean vineyard area. Agronomy, 10, 336.

27. Obia A., Mulder J., Martinsen V., Cornelissen G., Børresen T. 2016. In situ effects of biochar on aggregation, water retention and porosity in light-textured tropical soils. Soil and Tillage Reseach, 155, 35-44.

28. Ondrišík P. 2013. Dynamics of inorganic nitrogen in soil and possibilities of its regulation. SPU, Nitra, pp. 97. (in Slovak)

29. Ondrišík P., Urminská J. Porhajášová J., Ňanšanská M. 2009. Vplyv agrotechnických zásahov na sezónne zmeny anorganického dusíka $\mathrm{v}$ pôde. Journal of Central European Agriculture, 10(1), 101-107.

30. Pereg L., Morugán-Coronado A., McMillan M., García-Orenes F. 2018. Restoration of nitrogen cycling community in grapevine soil by a decade of organic fertilization. Soil \& Tillage Research, 179, 11-19.

31. Peterburskij A. 1963. Praktikum po agronomičeskoj chimii. Moskva: Izdanie Sel'skochozjajstvennoj Literatury, Žurnalov a Plakatov. (in Russian).

32. Plaza-Bonilla D., Álvaro-Fuentes J., CanteroMartínez C., 2015. Identifying soil organic carbon fractions sensitive to agricultural management practices. Soil \& Tillage Research, 139, 19-22.

33. Rutkowska A., Pikuła D. 2013. Effect of crop rotation and nitrogen fertilization on the quality and quantity of soil organic matter. In: Hernandez Soriano M.C. (Ed.), Soil Processes and Current Trends in Quality Assessment, pp. 249-267.

34. Saha R., Ghosh P. 2013. Soil organic carbon stock, moisture availability and crop yield as influenced by residue management and tillage practices in maizemustard cropping system under hill agro-ecosystem. National Academy Science Letters, 36, 461-468.

35. Saljnikov E., Cakmak D., Rahimgalieva S. 2013. Soil organic matter stability as affected by land management in steppe ecosystems. In: Hernandez 
Soriano, M.C. (Ed.), Soil Processes and Current Trends in Quality Assessment, pp. 269-310.

36. Šimanský V., Balashov E., Horák J. 2016. Water stability of soil aggregates and their ability to sequester carbon in soils of vineyards in Slovakia. Archives of Agronomy and Soil Science, 62, 177-197.

37. Šimanský V., Jonczak J., Kováčik P., Bajčan D. 2018. Impact of crop residues and biopreparations on nitrogen changes in Haplic Luvisol - model experiment. Soil Science Annual, 69, 251-258.

38. Šimanský V., Juriga M., Jonczak J., Uzarowicz L., Stapeń W. 2019. How relationships between soil organic matter parameters and soil structure characteristics are affected by the long-term fertilization of a sandy soil. Geoderma 342, 75-84.

39. Šimanský V., Polláková N. 2016. The effects of soil management practices on soil organic matter changes within a productive vineyard in the Nitra viticulture area (Slovakia). Agriculture (Pol’nohospodárstvo), 62(1), 1-9.

40. Standford G., Smith S.J. 1978. Oxidative release of potentially mineralizable soil nitrogen by acid permanganate extraction. Soil Science, 126(4), 210-218.
41. Szombathová N. 1999. The comparison of soil carbon susceptibility to oxidation by $\mathrm{KMnO} 4$ solutions in different farming systems. Humic substances in the environment, 1, 35-39.

42. Tong X., Xu M., Wang X., Bhattacharyya R., Zhang W., Cong R., 2014. Long-term fertilisation effects on organic carbon fractions in a red soil of China. Catena, 113, 251-259.

43. Vaněk V., Ložek O., Balík J., Pavlíková D., Tlustoš P. 2013. Nutrition of field and garden crops. Profi Press SK, Nitra. pp. 184. (in Slovak).

44. Vieira F.C.B., Bayer C., Zanatta J.A., Dieckow J., Mielniczuk J., He Z.L. 2007. Carbon management index based on physical fractionation of soil organic matter in an Acrisol under long-term no-till cropping systems. Soil \& Tillage Research, 96(1-2), 195-204.

45. Wang B., Liu D., Yang J., Zhu Z., Darboux F., Jiao J., An S. 2021. Effects of forest floor characteristics on soil labile carbon as varied by topography and vegetation type in the Chinese Loess Plateau. Catena, 196, 104825.

46. White RE. 2015. Understanding vineyard soils. Oxford University Press, New York. pp. 279. 